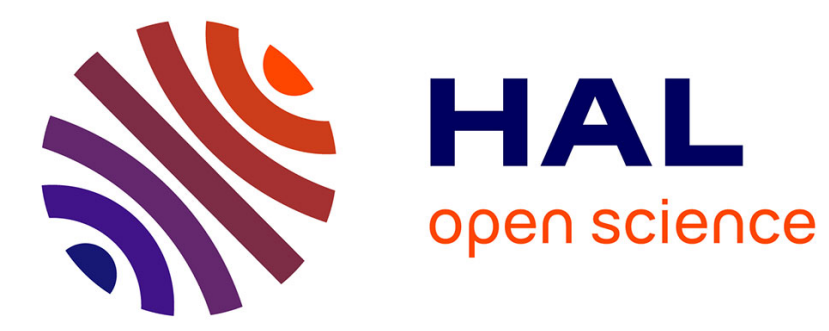

\title{
Sherman, Tamah Jiří Nekvapil: English in Business and Commerce: Interactions and Policies: English in Europe, Volume 5 (Book Review, Compte-rendu)
}

\author{
Marc Deneire
}

\section{- To cite this version:}

Marc Deneire. Sherman, Tamah Jiří Nekvapil: English in Business and Commerce: Interactions and Policies: English in Europe, Volume 5 (Book Review, Compte-rendu). Journal of English as a Lingua Franca, 2019, 8 (1), pp.161-165. 10.1515/jelf-2019-2007 . hal-02483469

\section{HAL Id: hal-02483469 \\ https://hal.science/hal-02483469}

Submitted on 18 Feb 2020

HAL is a multi-disciplinary open access archive for the deposit and dissemination of scientific research documents, whether they are published or not. The documents may come from teaching and research institutions in France or abroad, or from public or private research centers.
L'archive ouverte pluridisciplinaire HAL, est destinée au dépôt et à la diffusion de documents scientifiques de niveau recherche, publiés ou non, émanant des établissements d'enseignement et de recherche français ou étrangers, des laboratoires publics ou privés. 


\section{Sherman, Tamah, and Jiří Nekvapil (eds.) English in business and commerce: Interactions and policies: English in Europe volume 5. Boston and Berlin: de Gruyter. ISBN 978-1-5015-1553-8.}

This book is part of a series on English in Europe that takes as its starting point the questions addressed in conferences around the theme "English in Europe: opportunity or threat" that were held from January 2012 to October 2014 in Sheffield, Copenhagen, Zaragoza, Thessaloniki, and Prague. This fifth volume offers a rich collection of case studies that acknowledge two research findings: "(a) the fact that language choice tends not to be neutral and typically reflects power relationships (...) and (b) the fact that actual communicative needs in business and workplace situations require practical solutions, (...), which include the selection of a single lingua franca for pre-determined situations" (1-2). Papers have been grouped into three parts that reflect three overlapping approaches: (1) ideological and discursive approaches; (2) "The management of English in business and organizational contexts," and (3) The position of English and other languages on local and international labor markets, implication for language and education policy".

Part I explores the ideology of English in the business sphere, broadly defined by most authors along the lines of M. Silverstein as "any sets of beliefs about languages articulated by users as a rationalization or justification of perceived language structure and use" (97). In their "conversation across the table" (chap. 1), Andrew Lynn, the sociolinguist, and Guro Refsum Sanden and Rebecca Piekarri, the international business scholars, observe that that Einar Haugen's model of norm development elaborated in the Norwegian context with its four stages - (1) selection, (2) codification; (3) implementation, and (4) elaboration - also applies to the business context. Indeed, Grundfos, the company they use as a case study, functions on the belief that a single language is necessary for official international communication. Grundfos first selected one language (British English), further codified it as a company language, then implemented it through internal communication in the company, and finally, further elaborated it through the development of their own lexicons and dictionaries.

Following their interviews with 13 managers from 11 international companies based in Denmark (chap. 2), Kamilia Kraft and Dorte Lønsmann came to the conclusion that even though English is considered as "unproblematic" (59) among managers, it does not work as a lingua franca everywhere. Rather, they observed a "natural order of language choice" with Danish in the local context of Denmark, Scandinavian languages in the Nordic regions, and English in international settings. Often, the presence of blue-collar workers forces the use of multiple languages. Other languages are also used among expatriates to create more personal relationships. Finally, the authors note that the use of English creates an "illusion of equality" (63) especially in the presence of native speakers of English (Americans). In all cases, the choice of a specific language favors some groups above others and in most cases, it favors the managers who already have status and power (69). In chapter 3, Elisabeth Barakos shows how official bilingualism in Wales is used in terms of corporate identity and of other professional purposes, but is constantly mitigated on the grounds of practicality and economic rationality. As a result, Barakos points to an opposition between a top-down political agenda that preaches official bilingualism and bottom up "practical" economic realities that strongly reduce the impact such policies. In their comparison of two different European corporate case studies conducted in the banking sector, a major international Swiss bank and the subsidiary of a French bank in Italy (chap. 4), Alessia Cogo and Patchareerat Yanaprasart observe multiple and complex multilingual policies and practices. Contrary to the perception of most stakeholders who believe that English is the sole corporate language, each bank has 4 official languages. Even though English and German predominate in the Swiss bank, and Italian and 
French in the French bank, all languages are dominant in their local sectors (French in France, Italian in Italy, etc.) and all of them are used as lingua francas in international contexts. In these situations, business English as a lingua franca (BELF) is not "only English", but is shaped by multilingual repertoires; it is "a hybrid mixed from languaging and translanguaging" (108). The authors state that "corporate language is the black box of business communication studies, something obscure and alien, something that does not need to be investigated" (103) This may explain why most managers believe that English is the only official language of the company; they apply a monolingual ideology to a multilingual context, believing that languages need to be kept separate, but actually using them in a dynamic way.

The papers in part 2 place a greater emphasis on individual interactions among stakeholders. In chapter 5, Sharon Millar uses the concept of strategic management in her analysis of two Danish companies that introduced English as a corporate language in the early part of the $21 \mathrm{st}$ century. She notes that, beyond their differences, both companies were motivated by an "ideology of the absolute instrumentality" that ignores participation in the communicative process, linguistic rights or cultural considerations. Rather, the author notes, inadequate competence in English forces companies to adopt strategies of localization, thereby increasing, often unconsciously, power differentials between the different categories of employees and workers. Similarly, in her exploration of multilingual environments in the Japanese branches of multinationals, Lisa Fairbrother (chap. 6) found that it is not the "quality" of English that matters in interactions, but rather how it is used, by whom and to whom. Local sociolinguistic and socio-cultural norms often predominate. The author relates numerous anecdotes that exemplify how respect for hierarchical structure and face-saving strategies prevent lower-level competent employees from using their language skills to make the necessary adjustments in corporate and commercial encounters Sonia Barfod's study (chap. 7, interestingly titled "On the non-use of English in a multinational company") of interScandinavian communication in a German multinational company where English was introduced as a corporate language shows that outside formal meeting contexts, only Scandinavian languages are used, to the exclusion of English, and that the Danes, Norwegians, and Swedes adapt their language to their interlocutors' proficiency in the others' language. When common and full understanding is not of the essence, the use of one's first language facilitates phatic communication and social interaction and allows interlocutors to remain within their respective comfort zones. In chapter 8, Neil Bermel and Ludek Knittl adopted a linguistic landscape approach in their analysis of how languages interact in a Czech heritage site. They found that multilingualism on the site was of form of polylanguaging: the foreign language texts are not generated by communities of foreign origin but are part of the Czech linguistic toolkit. English and German are outward-facing, that is, they are used for communication with tourists in a very limited number of situations but in many others, they index status and lifestyle, adding cachet and modernity to products and services.

Papers in part 3 focus on the interaction between business and education. Most studies point to a wide discrepancy between the dominance of English in education and the "real" economic and societal language needs in economic contexts that are increasingly multilingual and multicultural. In chapter 9, Tobias Schroedler shows that the Irish economy relies heavily on exports to the other English-speaking countries, mainly the US, while those to nearby markets such as Germany and France are very weak. Using secondary quantitative data and interviews, he demonstrates that this trade deficit can be attributed to a lack of language resources. In Greece (chap. 10), Zoe Kantaridou, Iris Papadopoulou, and Jo Angouri note a discrepancy between the importance attached to English language learning by Greek society 
and market demands, as observed in job postings, the object of their study. Indeed, only 7.15 percent of the postings mention a language requirement. The authors point to the need to diversify the language offer in education, especially in Higher Education as other languages that are geographically and economically significant for Greece, such as Chinese, Balkan and Slavic languages. Unfortunately, these languages are almost completely absent from the curriculum. In chapter 11, Vit Dovalil explores the decision-making processes regarding the choice of foreign languages among institutions, parents, and educators in the Czech Republic. He observes that in spite of a perceived need for German in the economic sphere, English remains prevalent both in official language policy and on the ground. In chapter 12. Miya Komori-Glatz and Barbara Schmidt-Unterberger report on their respective research projects on English-medium instruction (EMI) at the Vienna business school. Their surveys show that the management's motivation to improve the school's competitiveness and the aim to improve the students' preparedness for international business through English are generally satisfied. However, they regret that language learning is largely considered as an incidental benefit and wonder how language teaching could be optimized in this context. In the final chapter, Alla Tovares and Nkonko Kamwangamalu observe that there is an unequaled demand for English in both Kenya and in South Africa, in spite of governmental efforts to develop and implement regional and local languages (e.g. Kiswahili and isiZulu). They note that English-medium education is cost-prohibitive for most of the population and therefore excludes more than it includes; therefore, it is also costly for African economies. As a result, they strongly advocate prestige planning for African languages, a form of planning that also involves economic gains. Indeed, it is only if African languages become associated with economic value that they have a chance of becoming equal partners with English on the African linguistic market.

English in business and commerce will be of interest to both sociolinguists and scholars in business communication. Each contribution successfully illustrates the complexity of multilingual and multicultural interactions in specific context. All the papers endeavor, sometimes painstakingly, to expose their theoretical background and methodology, which, unfortunately, sometimes leads to a measure of self-referentiality reflected in the use of "stock phrases" throughout the volume. Further, the overuse of some specific references contributes perhaps to the coherence of the volume, but not always to the argument. In terms of methodology, the almost exclusive use of interviews among managers ends up giving a fairly one-sided view of the business world. Many contributors recognize the use of English in power relations as well as its gatekeeping function, but this reader would have liked to hear the voices of those employees and workers who are on the other side of the gate.

In terms of language use, the picture that comes out of the book is one of situations where, in the words of Cogo and Yanaprasat, all languages are used at the same time (ALAST), as opposed to one language at a time (OLAT), or one language only (OLON). As one might expect, business English as a lingua franca (BELF) is itself mixed with other languages, highly hybrid, fluid, and volatile. The editors' suggestion that communicative needs in business require the use of a single lingua franca (2) is, indeed, limited to a very small number of formal situations.

All in all, this volume is rich in examples that invite us to complexify the limited number of $a$ priori categories which we sometimes use when apprehending concrete linguistic interactions. It will be of interest to any student and scholar willing to join in this collective effort. 